interest in animal life, especially in the relations between plants and animals, in insects as pollinators and pests, and in birds and mammals as distributors of plants.

He thus went to Singapore in 1888 (as director of Gardens and Forests, Straits Settlements) well equipped to make the pioneer investigations of plant and animal life which were then needed, and to them he devoted the next twenty-three years of his life. In addition to the wide scope of his knowledge and interest, his other prime characteristic was the intensity of purpose with which he applied himself to everything that he did. With small financial resources, and little help from others, he achieved original pioneer work of a variety and scope such as few men have accomplished in a comparable period of time.

By his investigation of the tapping of Para rubber trees, and his persistent advocacy of the need for, and possibility of, a plantation rubber industry, he was largely responsible for making possible the development of modern Malaya. He was a wonderful field botanist, because he knew and could recognize such a great range of plants; he knew at once if he was looking at something new and interesting, when another collector might pass it unnoticed. He took every opportunity of travelling, and made by far the largest single contribution to our present knowledge of the Malayan flora. Several species of plants are still known only from his original specimens.

In addition to Para rubber, Ridley cultivated experimentally many other useful plants from outside Malaya. He wrote reports upon these plants, and on the techniques of handling them for local use. He also investigated, and reported upon, the many kinds of timber trees and other useful plants of the Malayan forest. His zoological papers were numerous and varied.

But because he had so many interests, and attempted such a wide range of work, and because he had so little help, everything he did was done in a hurry, and there is frequent evidence of this in Ridley's published papers and books. One thing he apparently had not the ability (or the patience) to do was to correlate his observations with those of other people; and through the habit of hasty work he apparently lost the ability of making careful and methodical records of his own observations. But it is not as a finished worker one must judge him; he was a pioneer, and showed the way for others who came afterwards, each to deal with only a fraction of the field he tried to cover.

Among those who travelled with him on his expeditions (as some of them have told me) Ridley had the reputation of being a good companion, always cheerful and resourceful. In his later years he had an inexhaustible fund of stories of his life in Malaya, and greatly enjoyed recounting them; from them one could appreciate his zest for life. He had a fine scorn of those with whom he disagreed, but a warm heart that made him beloved by many, especially by those to whom he quietly and generously gave practical help in time of need. One of his larger benefactions, which (at his own request) was nover publicly announced, was a considerable gift towards the cost of A. F. R. Wollaston's expedition to New Guinea in 1912-13 (see Geographical Journal, 43, 248-268).

At the age of eighty-two, Ridley married Lily Doran, who, with her sister, most devotedly cared for him during his later years and in his final illness.

R. E. HoltTum

\section{Prof. Doris L. Mackinnon}

After an illness lasting almost three months, Prof. Doris Livingston Mackinnon died on September 10, at the age of seventy-two. She was the eldest of five talented children born to Lachlan Mackinnon, advocate of Aberdeen, and Theodora Mackinnon, née Thompson, of London, and she was born on September 30, 1883. Doris could draw slkilfully, she had a good knowledge of music, and she had a great literary gift. Why then did she choose science as a career " Her father, who was a lover of animals, as well as an ardent, amateur botanist, ornithologist and astronomer, would take the children for rambles in the country, to observe Nature in all its forms. Another influence in Doris's life was that of the late Mrs. Ogilvie Gordon, a noted geologist, who encouraged her to take up science serinusly. She took her B.Sc. at the University of Aberdeen with the subjects botany, zoology and geology, graduating with distinction in 1906 and being, as I believe, the second woman to be capped in that University. A Carnegie Scholarship then enabled her to spend one year in the laboratory of Richard Hertwig at Munich, some months at the Biological Station at Roscoff, collaborating with M. F. Vles in protozoological research, and a further period in the Quick Laboratory at Cambridge under the supervision of Prof. G. H. F. Nuttall.

During 1908-9 Miss Mackinnon acted as personal assistant to Prof. J. Arthur Thomson at Marischal College, Aberdeen, and in 1909 she was invited by Prof. W. D'Arcy 'Thompson to become his assistant at University College, Dundee. She remained in Dundee until the spring of 1916, and was then granted leave of absence to undertake war-work. During these years she established her reputation both as a brilliant lecturer and a protozoologist. In addition to her academic work, she gave a number of popular lectures in Dundee, Perth and Aberdeen, and by 1914, when she gained the degree of D.Sc. at Aberdeen, she had published fourteen papers, most of them dealing with the parasites of insects. In May 1916 she came under the influence of Clifford Dobell, who trained her at the Wellcome Burearr in matters relating to the study of amoubic dysentery. Another potent influence was that of her father's first cousin, Sir Patrick Manson. She then took up a War Office appointment as protozoologist attached to military hospitals. At the Ist Western General Hospital and at the School of Tropical Medicine, Liverpool, and later (1917) at the University War Hospital, Southampton, she collaborated with a number of colleagues in the pub. lication of several important papers and reports concerned with lintamoeba histolytica and amobic dysentery.

In 1918, when D'Arcy Thompson accepted the chair at St. Andrews, the Couneil of University College, Dundee, obtained her release from war-work, and she returned in April, running the Zoology Dopartment single-handed. A year later she was appointed Prof. Arthur Dendy's senior lecturer at King's College, London, and in 1927 she became professor of zoology in the College.

Prof. Mackinnon's contributions to the original literature on her subject, most of which were concerned with the parasitic Protozoa, numbered about forty papers. Her sound knowledge of German was utilized in the translation of J. von Uexküll's "Theoretische Biologie" (1926) and in a translation of a musical book by Paul Mies, "Beethoven Sketches, 
an Analysis of his Style, based on his Sketchbook" (1929). She also edited Berg's "Nomogenesis". Another side of her character is revealed by numerous articles, many of them studies of children and some of them childhood memories, which wore published during the period 1913-19 in the Manchester Guardian and other periodicals. A course of broadcast talks for schools formed the basis of her book "The Animal's World" (1936), which appeals to adults even more than to children, and which reached an enlarged new edition in 1950. For many years Prof. Mackinnon worked on the preparation of her opus magnum, an illustrated text-book on protozoology, but she did not live to see this work quite completed. There is every hope, however, that it will appear in the near future, and those knowing the unusually fine quality of her teaching will look forward to its appearance.
As a colleague of Prof. Mackinnon for twenty years, I can vouch for the smoothness with which she ran her Department. She was an able administrator, and such a friend to her staff that her merest wish was equal to her command. Always ready to seek advice on such technical matters as perplexed her, she was equally ready to offer guidance to staff and students, whether on academic or personal matters. Many would testify to her kindness to them, for she lived for communion with her students, past and present. How she found time and energy to write to so many students so often and so fully, I for one cannot guess ; but her self-imposed duty must have given joy both to herself and to many, particularly during the arduous years of war. All who have known Prof. Mackinnon will feel deeply saddened by the passing of a charming and gracious lady.

BEN DAWES

\section{NEWS and VIEWS}

\section{Appeal from the University of Szeged, Hungary}

The following communication, dated November 4, has been received from Prof. A. Szent-Gyorgyi, of the Marine Biological Laboratory, Woods Hole, Mass. : "I obtained from Hungary the wire quoted below, posted on November the 3rd, 6 p.m. I should be grateful if you could give room to it on your pages. "To A. Szent-Gyorgyi, Marine Research Laboratory, Woods Hole, Massachusetts, U.S.A. The University of Szeged makes the following declaration : the newly born democratic Hungary wants to live in peace and friendship with its neighbours and all peoples of the world. We call on all Universities to support and help us with their moral authority in our endeavour to restore peace and independence to our country, which are the basic conditions of all scientific work. We ask all those men of learning with whom we established contacts at home or abroad, to come to our help. Up to the present we strived with all the modest means at our disposal to serve the progress and better future of mankind. We want also in the future to do everything possible to work in concert with the researchers of the whole world. We would be overjoyed if this desire could be fulfilled. We ask you to make this declaration known in possibly wide circles.' Here follows a great number of signatures, representing practically the whole senate and faculty."

\section{Nobel Prize in Chemistry for 1956}

Tue Nobel Prize in Chemistry has this year been divided between Sir Cyril Hinshelwood, president of the Royal Society and Dr. Lee's professor of chemistry in the University of Oxford, and Prof. N. Semenov, of the Academy of Sciences, Moscow, for their work on the kinetics of chemical reactions.

\section{Sir Cyril Hinshelwood, F.R.S.}

Sir Cyril Hinshelwood was elected president of the Royal Society in 1955, and reference was made to his many interests in Nature of December 10, 1955, p. 1101. This further honour which has come to him is a worthy recognition of the fundamental significance of his work on the study of chemical processes by kinetic methods.
Academician N. Semenov

Nikolar Nikolaievich Semenov, member of the U.S.S.R. Academy of Sciences and director of the Institute of Chemical Physics in Moscow, to whom, jointly with Sir Cyril Hinshelwood, this year's Nobel Prize for Chemistry is awarded, has long been known to all chemists for his outstanding contributions to the theory of chain reactions and explosions. The first major impact of his ideas on the world came with the explanation in terms of branching reaction-chains of the sudden ignition on slight increases of pressure of mixtures such as phosphorus vapour and oxygen in which, below the limiting pressure, there is little sign of chemical activity. His book, "Chemical Kinetics and Chain Reactions", published in England in 1935, contains an exhaustive analysis of the applications of the chain-theory to reactions of the most varied types, but notably to those involved in combustion processes. Among the many fruitful ideas which Semenov has advanced is that of degenerate branching, in terms of which some of the rather mysterious phenomena associated with the induction periods of oxidation reactions can be understood. Less well known, because published only in Russian, is his work on the propagation of explosion waves. Semenov has been, and still is, the centre of a distinguished group of Russian workers in various fields of physical chemistry, but principally devoted to the study of the mechanism of chemical transformation. It is an interesting circumstance that the two chemists who share this year's award have been on very friendly terms for many years, and met in Moscow on the occasion of the Academy's celebration of its 220th anniversary in 1945 .

\section{Royal Society: Medal Awards for 1956}

The QUEen has been graciously pleased to approve the following recommendations made by the Council of the Royal Society for the award of the two Royal Medals: Dr. Dorothy M. C. Hodgkin, reader in X-ray crystallography, University of Oxford, for her distinguished work in the elucidation of the structures of penicillin, vitamin $B_{12}$ and other important compounds by the methods of X-ray crystallography; Dr. O. T. Jones, lately Woodwardian professor of geology in the University of Cambridge, for his 